This is an author produced version of a paper published in Neurobiology of Disease. This paper has been peer-reviewed but does not include the final publisher proof-corrections or journal pagination.

Citation for the published paper:

Mansson, Roland and Hansson, Magnus J and Morota, Saori and Uchino, Hiroyuki and Ekdahl, Christine T and Elmér, Eskil.

"Re-evaluation of mitochondrial permeability transition as a primary neuroprotective target of minocycline"

Neurobiology of Disease, 2006, Issue: Oct 23.

http://dx.doi.org/10.1016/j.nbd.2006.09.008

Access to the published version may require journal subscription.

Published with permission from: Elsevier 


\title{
Re-evaluation of mitochondrial permeability transition as a primary neuroprotective target of minocycline
}

\author{
Roland Månsson, ${ }^{\mathrm{a}, \mathrm{b}, *}$ Magnus J. Hansson, ${ }^{\mathrm{a}}$ Saori Morota, ${ }^{\mathrm{d}, \mathrm{e}}$ Hiroyuki Uchino, ${ }^{\mathrm{e}}$ Christine T. Ekdahl, ${ }^{\mathrm{c}}$ and \\ Eskil Elmér,
}

${ }^{a}$ Laboratory for Experimental Brain Research, Department of Clinical Sciences, Lund University, Sweden

${ }^{b}$ Department of Neurology, Malmö University Hospital, Malmö, Sweden

${ }^{c}$ Section of Restorative Neurology, Department of Clinical Sciences, Lund University, Sweden

${ }^{d}$ Laboratory of Cellular Neurobiology, School of Life Science, Tokyo University of Pharmacy and Life Science, Hachioji, Japan

${ }^{e}$ Department of Anesthesiology, Tokyo Medical University Hachioji Medical Center, Tatemachi, Hachioji, Japan

* Address correspondence to Roland Månsson, Laboratory for Experimental Brain Research, Wallenberg Neuroscience
Center, BMC A13, SE-221 84 Lund, Sweden Tel: +46 46 2220605, Fax: +46 46 2220615, E-mail: roland.mansson@med.lu.se

\begin{abstract}
Minocycline has been shown to be neuroprotective in ischemic and neurodegenerative disease models and could potentially be relevant for clinical use. We revisited the hypothesis that minocycline acts through direct inhibition of calcium-induced mitochondrial permeability transition (mPT) resulting in reduced release of cytochrome $c$ (cyt $c$ ). Minocycline, at high dosage, was found to prevent calcium-induced mitochondrial swelling under energized conditions similarly to the mPT inhibitor cyclosporin A (CsA) in rodent mitochondria derived from the CNS. In contrast to CsA, minocycline dose-dependently reduced mitochondrial calcium retention capacity (CRC) and respiratory control ratios and was ineffective in the de-energized mPT assay. Further, minocycline did not inhibit calcium- or tBid-induced cyt $c$ release. We conclude that the neuroprotective mechanism of minocycline is likely not related to direct inhibition of $\mathrm{mPT}$ and propose that the mitochondrial effects of minocycline may contribute to toxicity rather than tissue protection at high dosing in animals and humans.
\end{abstract}

Keywords: Neurodegeneration, Amyotrophic lateral sclerosis, Huntington's disease, Parkinson's disease, Motor neuron disease, Spinal cord injury, Ischemia, Apoptosis, Cyclosporin, Minocycline, Neuroprotection, Brain mitochondria

\section{Introduction}

Minocycline is a second-generation tetracycline derivative that has displayed neuroprotective properties in a broad range of models of neurological disease e.g. global and focal ischemia, brain and spinal cord trauma, as well as Alzheimer's, Huntington's and Parkinson's disease (Arvin et al., 2002; Casarejos et al., 2006; Chen et al., 2000; Choi et al., 2005; Du et al., 2001; Festoff et al., 2006; Ryu et al., 2004; Sanchez Mejia et al., 2001; Teng et al., 2004; Yong et al., 2004; Yrjanheikki et al., 1998; Yrjanheikki et al., 1999). Furthermore, minocycline has prolonged life span in the most widespread model for amyotrophic lateral sclerosis (ALS), mice carrying a human mutation of superoxide dismutase (SOD) associated with familial ALS (Kriz et al., 2002; Van Den Bosch et al., 2002; Zhu et al., 2002). The mechanisms of the neuroprotective action are currently unknown. Minocycline has been reported to influence the expression and activity of e.g. caspases and nitric oxide synthase, inhibit reactive microgliosis, induce the anti-apoptotic protein $\mathrm{Bcl}-2$ and display antioxidant properties (Chen et al., 2000; Kraus et al., 2005; Tikka et al., 2001; Wang et al., 2004).

Recently, several reports have concluded that mitochondria are key targets for the neuroprotective action of minocycline via direct inhibition of mitochondrial permeability transition $(\mathrm{mPT})$ and the subsequent release of pro-apoptotic proteins from the intermembrane space (Teng et al., 2004; Wang et al., 2003; Zhu et al., 2002). Inhibition of $\mathrm{mPT}$ is a feasible target for neuroprotection and its definition 
includes a sudden increase in permeability of the inner mitochondrial membrane leading to loss of electrochemical gradients and uncoupling of oxidative phosphorylation, overt mitochondrial swelling and release of $\mathrm{Ca}^{2+}$ and intermembrane proteins such as cytochrome $c$ (cyt $c$ ) to the surrounding cytosol (Halestrap et al., 2004). The mPT inhibitor cyclosporin A (CsA) has exhibited neuroprotective properties when allowed to penetrate the blood-brain barrier in several animal models of ischemia, brain trauma and hypoglycemic coma (Friberg et al., 1998; Matsumoto et al., 1999; Sullivan et al., 2000; Uchino et al., 1998). Inhibition of mPT may also prove to be a beneficial therapy for neurodegenerative diseases. Mitochondria from the spinal cord of transgenic ALS mice have been shown to have an impaired $\mathrm{Ca}^{2+}$ retention capacity, possibly contributing to neuronal degeneration (Damiano et al., 2006). Intrathecal administration of CsA to transgenic ALS mice (SOD1 G93A) extend the remaining life span at late stage disease (Keep et al., 2001) and delay onset of symptoms, prevent neuronal death and increase overall life span by presymptomatic treatment (Karlsson et al., 2004).

To investigate the mPT-related neuroprotective mechanism for minocycline, its influence on the release of certain pro-apoptotic proteins, e.g. cytochrome $c$ (cyt $c$ ), Smac/Diablo and apoptosis inducing factor (AIF), has been studied in tissue homogenates, cell cultures and preparations of isolated mitochondria (Wang et al., 2003; Zhu et al., 2002). One feature of the studies performed on isolated brain (and liver) mitochondria is the relatively high concentration/dose of minocycline needed to prevent the mitochondrial release of proteins following various triggering events (e.g. $\mathrm{Ca}^{2+}$, tBid and oxidants) compared to concentrations needed to reach its anti-inflammatory effect (Tikka et al., 2001; Yrjanheikki et al., 1999). High systemic dosing of minocycline has also been employed in some animal models, e.g. $180 \mathrm{mg} / \mathrm{kg}$ i.p. in a spinal cord injury study (Teng et al., 2004). A dosing regimen of $90 \mathrm{mg} / \mathrm{kg}$ the first day followed by 45 $\mathrm{mg} / \mathrm{kg}$ i.p. injections in the rat would correspond to approximately $1.5 \mathrm{~g} /$ day (p.o.) in humans (Scarabelli et al., 2004) which can be compared to the mean tolerated dose of $387 \mathrm{mg} /$ day (p.o.) in a clinical phase II study (Gordon et al., 2004).

Minocycline is currently available for human use and presently in, or planned for, human clinical trials in neuroprotection (Gordon et al., 2004; Huntington
Study Group, 2004; Yong et al., 2004). The selection of human dosing is limited by tolerability but preclinical studies of its neuroprotective action will naturally impact the target dosing. It is, therefore, warranted to elucidate the relevant molecular targets of minocycline.

In the present study we revisited the conclusion that minocycline directly inhibits the induction of $\mathrm{mPT}$ and release of pro-apoptotic proteins in brain-derived rodent mitochondria. The objectives were to investigate the effect of a wide concentration/dose range of minocycline in several models of $\mathrm{Ca}^{2+}$ induced $\mathrm{mPT}$, as well as evaluate the effect of minocycline on $\mathrm{Ca}^{2+}$ - and tBid-induced release of cyt $c$ and evaluate the influence of minocycline on mitochondrial respiratory function.

\section{Materials and methods}

All animal procedures were approved by the Malmö/Lund Ethical Committee for Animal Research (M221-03, M230-03). Adult male Wistar rats and C57 mice were used. Chemicals were from Sigma (St. Louis, MO) unless otherwise indicated. Isolation of rodent brain or spinal cord mitochondria was achieved using a discontinuous Percoll gradient, as previously described (Hansson et al., 2003; Sims, 1990). In brief, rats were decapitated and the brain or the spinal cord was rapidly removed to ice-cold isolation buffer (IB), containing $320 \mathrm{mM}$ sucrose, 2 $\mathrm{mM}$ EGTA, $10 \mathrm{mM}$ Trizma base, $\mathrm{pH}$ 7.4. Approximately $600 \mathrm{mg}$ of cortical or spinal tissue was homogenized in IB $(10 \% \mathrm{w} / \mathrm{v})$ containing $12 \%$ (v/v) Percoll. The homogenate was added to a Percoll gradient, $40 \%$ and $26 \%$ respectively, and centrifuged in a Beckman ultracentrifuge 100.3 rotor at $30700 \mathrm{~g}$ for $7 \mathrm{~min}$, yielding a dense fraction 3 . The latter was collected and washed twice in successive centrifugational steps to remove remaining percoll, $16700 \mathrm{~g}$ for $12 \mathrm{~min}$ and $7400 \mathrm{~g}$ for $7 \mathrm{~min} .0 .05 \%$ BSA was present during the last centrifugation. The final pellet was resuspended and diluted in IB to a fixed concentration after protein quantification according to Bradford (Bradford, 1976) using BSA as standard.

A luminescence spectrometer LS-50B (Perkin-Elmer, Emeryville, CA) with a temperature controlled cuvette holder was used for all fluorescence experiments. $\mathrm{Ca}^{2+}$-induced $\mathrm{mPT}$ was observed in mitochondrial suspensions $(25 \mu \mathrm{g} / \mathrm{ml})$ by measuring the decrease in $90^{\circ}$ light scattering at $520 \mathrm{~nm}$ reflecting mitochondrial swelling or by monitoring 
extramitochondrial $\mathrm{Ca}^{2+}$ with the fluorescent probe Calcium Green 5N, (Molecular Probes, Eugene, OR, $100 \mathrm{nM}$ ) following a bolus dose of $\mathrm{Ca}^{2+}$. In addition, in order to minimize bioenergetic influence of bolus administration, mitochondria $(50 \mu \mathrm{g} / \mathrm{ml})$ were exposed to a continuous $(200 \mathrm{nmol} / \mathrm{min} / \mathrm{mg}) \mathrm{Ca}^{2+}$. infusion and the mitochondrial $\mathrm{Ca}^{2+}$-retention capacity was determined (Chalmers et al., 2003).

Analyses of $\mathrm{Ca}^{2+}$-induced $\mathrm{mPT}$ and extramitochondrial $\mathrm{Ca}^{2+}$ following a bolus dose of $\mathrm{Ca}^{2+}$ were performed under energized conditions (Hansson et al., 2004), in a sucrose-based buffer (250 $\mathrm{mM}$ sucrose, $20 \mathrm{mM}$ MOPS, $10 \mathrm{mM}$ Trizma base, 2 $\mathrm{mM} \mathrm{P}_{\mathrm{i}}(\mathrm{K}), 1 \mathrm{mM} \mathrm{MgCl} 2,1 \mu \mathrm{M}$ EGTA, $\mathrm{pH}$ 7.2) containing $1 \mu \mathrm{g} / \mathrm{ml}$ oligomycin and $20 \mu \mathrm{M}$ ADP at $37^{\circ}$ with $5 \mathrm{mM}$ malate and glutamate as respiratory substrates.

For de-energized conditions (Hansson et al., 2003), an isotonic $\mathrm{KCl}$ buffer at $28^{\circ} \mathrm{C}, \mathrm{pH} 7.3$, containing $150 \mathrm{mM} \mathrm{KCl}, 20 \mathrm{mM}$ MOPS and $10 \mathrm{mM}$ Trizma base was used. Addition of $2 \mathrm{mM}$ nitrilotriatcetic acid (NTA) provided calcium buffering. The respiratory complexes were inhibited with $0.5 \mu \mathrm{M}$ rotenone and $0.25 \mu \mathrm{g} / \mathrm{ml}$ antimycin A. Two $\mu \mathrm{M}$ of the $\mathrm{Ca}^{2+}$-ionophore (A23187) allowed free diffusion of $\mathrm{Ca}^{2+}$ into the mitochondrial matrix. The ionophore alamethicin $(7.5 \mu \mathrm{g} / \mathrm{ml})$ was added to induce a standardized maximal swelling response of the mitochondrial population.

Calcium-infusion experiments were performed under energized conditions using $\mathrm{KCl}$ buffer $(125 \mathrm{mM}$ $\mathrm{KCl}, 20 \mathrm{mM}$ Trizma base, $2 \mathrm{mM} \mathrm{P}_{\mathrm{i}}(\mathrm{K}), 1 \mathrm{mM}$ $\mathrm{MgCl}_{2}, 1 \mu \mathrm{M}$ EGTA, pH 7.2) with $5 \mathrm{mM}$ malate and glutamate as respiratory substrates and $1 \mu \mathrm{g} / \mathrm{ml}$ oligomycin and $200 \mu \mathrm{M}$ ADP present.

Respiratory activities of brain and spinal mitochondrial preparations $(0.25 \mathrm{mg} / \mathrm{ml})$, were measured by determining $\mathrm{O}_{2}$ consumption in airtight chambers at $30^{\circ} \mathrm{C}$, using Clark-type $\mathrm{O}_{2}$ electrodes (Hansatech, Norfolk, UK). $5 \mathrm{mM}$ malate and glutamate were present as respiratory substrates and the same buffer was used as in the calcium-infusion experiments. Respiratory control ratios (RCR) were calculated as the ratio of $\mathrm{O}_{2}$ consumption during active phosphorylation in presence of ADP (state 3) to resting rate after ADP was consumed (state 4). The effect of minocycline and CsA on respiration was evaluated simultaneously to vehicle in parallel chambers.

An ELISA kit (Quantikine ${ }^{\circledR}$ M, R\&D Systems, Abingdon, UK) was employed to measure cyt $c$ release. Experiments were run under energized conditions. Rat and mouse brain mitochondria (50 $\mu \mathrm{g} / \mathrm{ml})$ were exposed to 1.4 and $1.2 \mu \mathrm{mol} \mathrm{Ca}^{2+} / \mathrm{mg}$, respectively, for $10 \mathrm{~min}$. In addition, rat brain mitochondria were exposed to $100 \mathrm{ng} / \mathrm{ml}$ truncated $\mathrm{Bid}$ (tBid) for $30 \mathrm{~min}$, conditions previously found to induce maximal cyt $c$ release (Brustovetsky et al., 2003). A protease inhibitor cocktail (Sigma P-2714) was added $60 \mathrm{~s}$ after the $\mathrm{Ca}^{2+}$ insult or after tBid incubations. Mitochondria were pretreated with minocycline, $1 \mu \mathrm{M}$ CsA or vehicle to test for inhibition of cyt $c$ release. Following incubations, mitochondrial suspensions were rapidly chilled and centrifuged at $7000 \mathrm{~g}$ for $10 \mathrm{~min}$. A second centrifugation of supernatants at 436,000 $g$ for 60 min was performed before determining cyt $c$ content.

Minocycline was prepared daily and dissolved in Millipore water. Both concentration $(\mu \mathrm{M})$ and dose (nmol/mg mitochondrial protein) are provided as the mitochondrial protein content varied between the assays. Minocycline was evaluated using concentrations of $1-100 \mu \mathrm{M}(40-4000 \mathrm{nmol} / \mathrm{mg}$ mitochondrial protein) in the energized swelling assay, $2.5-250 \mu \mathrm{M}(100-10,000 \mathrm{nmol} / \mathrm{mg})$ in the deenergized swelling assay, $0.2-20 \mu \mathrm{M} \quad(4-400$ $\mathrm{nmol} / \mathrm{mg}$ ) in the calcium-infusion experiments, 1-20 $\mu \mathrm{M}(80-400 \mathrm{nmol} / \mathrm{mg})$ for inhibition of cyt $c$ release and $15-150 \mu \mathrm{M}(40-400 \mathrm{nmol} / \mathrm{mg})$ for respiratory measurements.

All experiments were replicated in 3-4 separate mitochondrial preparations using malate and glutamate as respiratory substrates. Statistical analyses were performed using one-way ANOVA with Bonferroni post hoc test.

\section{Results}

Minocycline significantly reduced swelling in energized, respiring brain mitochondria induced by $\mathrm{Ca}^{2+}$ bolus load (Fig. 1A upper panel, 1B). The inhibitory effect of minocycline was seen at the higher concentrations tested, 25 and $100 \mu \mathrm{M}(800$ and $4000 \mathrm{nmol} / \mathrm{mg}$ mitochondrial protein) in mouse and rat brain mitochondria, respectively. At lower concentrations, there was a tendency for minocycline to potentiate the swelling response to $\mathrm{Ca}^{2+}$, which was significant at $2.5 \mu \mathrm{M}$ in mouse brain mitochondria. Spinal cord mitochondria exhibited a similar dose-response relationship. However, no significant reduction of swelling was detected, and 1 and $10 \mu \mathrm{M}$ minocycline significantly increased the swelling response (Fig. 1B). 
A
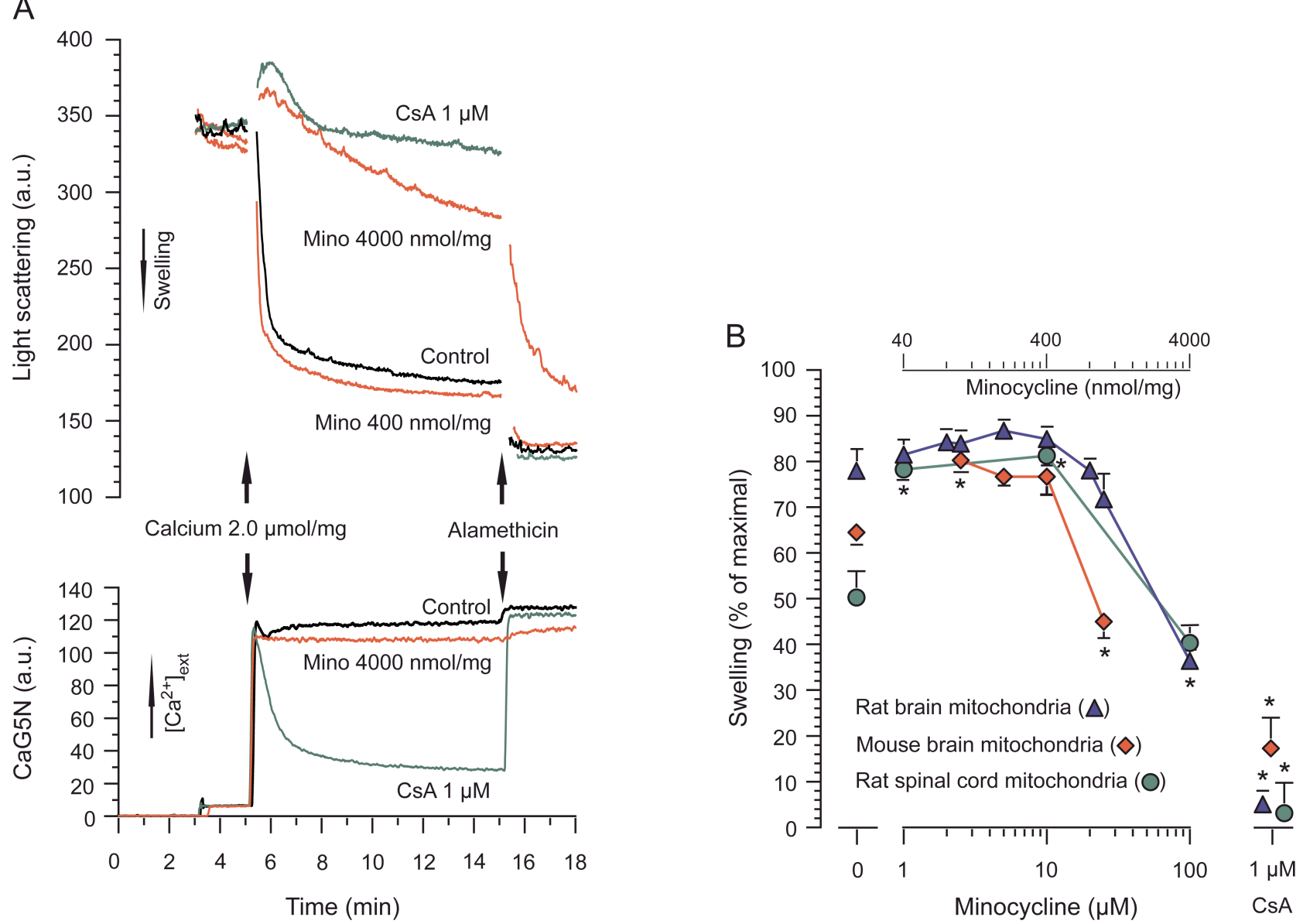

\section{Figure 1}

Minocycline reduces $\mathrm{Ca}^{2+}$-induced mitochondrial swelling at high doses but does not enable $\mathrm{Ca}^{2+}$ uptake. (A) Representative traces of changes in light scattering (upper panel, arbitrary units, $520 \mathrm{~nm}$ ) and changes in Calcium Green $5 \mathrm{~N}$ fluorescence (lower panel, arbitrary units) of isolated rat brain mitochondria. A decrease in scattering reflects mitochondrial swelling whereas a decrease in Calcium Green fluorescence indicates a decrease in extramitochondrial $\mathrm{Ca}^{2+}$ (mitochondrial $\mathrm{Ca}^{2+}$ uptake). Mitochondria $(25 \mu \mathrm{g} / \mathrm{ml}) \mathrm{were}$ incubated in a sucrose-based buffer at $37^{\circ} \mathrm{C}$ containing $1 \mu \mathrm{g} / \mathrm{ml}$ oligomycin, $20 \mu \mathrm{M}$ ADP, and $5 \mathrm{mM}$ malate and glutamate as respiratory substrates.

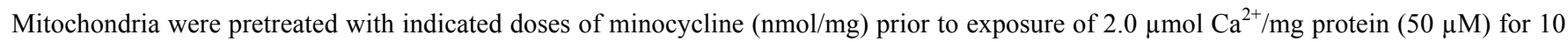
min. Cyclosporin A and vehicle $\left(\mathrm{H}_{2} \mathrm{O}\right)$ were used as positive and negative controls, respectively. The ionophore alamethicin $(7.5 \mu \mathrm{g} / \mathrm{ml}) \mathrm{was}$ added to induce a standardized maximal swelling response of the mitochondrial population. Trace disturbances during additions have been deleted for clarity. (B) Calculations of the extent of swelling of the mitochondrial population (the decrease in light scattering following Ca ${ }^{2+}$ compared to that of alamethicin, expressed as \% of maximal) for experiments with rat and mouse brain and rat spinal cord mitochondria. Values are means \pm SEM. * indicate $p<0.05$, treatment vs. vehicle (control).

Mitochondrial $\mathrm{Ca}^{2+}$ handling was investigated under the same conditions used in Fig. 1A upper panel and are illustrated in the lower panel of Fig. 1A. Following the bolus dose of $\mathrm{Ca}^{2+}$, untreated mitochondria were unable to sequester the added $\mathrm{Ca}^{2+}$, which can be attributed to an mPT rapidly counteracting the initial uptake. With the mPT inhibitor CsA present, mitochondria sequestered and retained the $\mathrm{Ca}^{2+}$ until they were unspecifically permeabilized by alamethicin. At $100 \mu \mathrm{M}$ minocycline, which inhibited swelling, mitochondrial sequestering of $\mathrm{Ca}^{2+}$ was not detectable.
In mitochondria exposed to a continuous $\mathrm{Ca}^{2+}$ infusion, minocycline dose-dependently decreased the calcium retention capacity (CRC), which approached zero at $20 \mu \mathrm{M}(400 \mathrm{nmol} / \mathrm{mg})$. CsA (1 $\mu \mathrm{M})$ increased the CRC from $1.58 \pm 0.15$ to $3.62 \pm 0.38$ $\mu$ mol Ca ${ }^{2+} / \mathrm{mg}$ mitochondria (Fig. 2). Blocking the $\mathrm{Ca}^{2+}$ uniporter with $1 \mu \mathrm{M}$ ruthenium red prevented $\mathrm{Ca}^{2+}$ retention (Fig. 2A) as did uncoupling by the protonophore CCCP (carbonyl cyanide $\mathrm{m}$ chlorophenylhydrazone) at $400 \mathrm{nM}$. Uncoupling mitochondria prior to $\mathrm{Ca}^{2+}$ bolus exposure also prevented swelling (data not shown). 
A
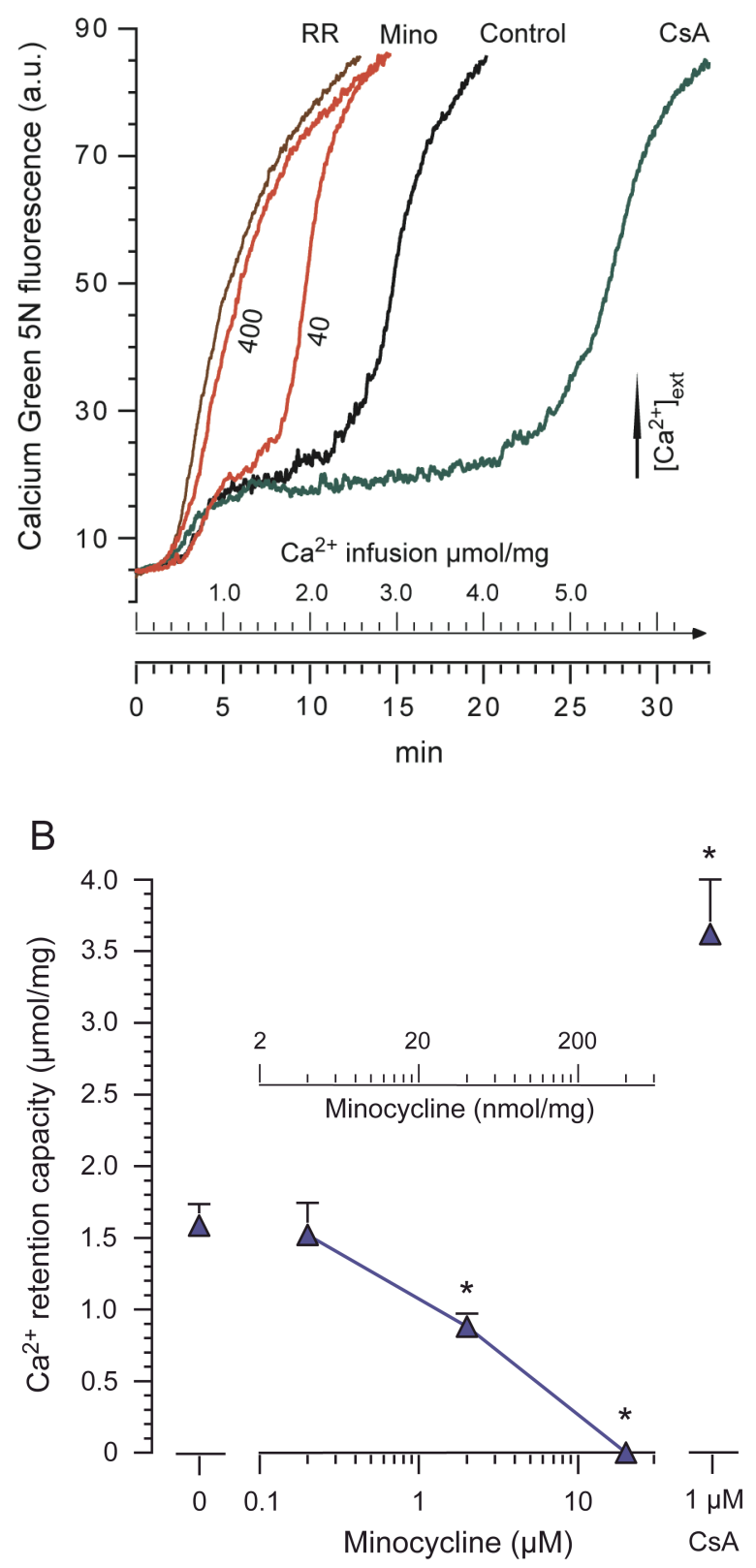

\section{Figure 2}

Minocycline dose-dependently reduces calcium retention capacity of mitochondria exposed to a continuous calcium infusion. (A) Representative traces of changes in Calcium Green $5 \mathrm{~N}$ fluorescence (arbitrary units). An increase in fluorescence indicates an increase in extramitochondrial calcium concentration. Rat brain mitochondria $(50 \mu \mathrm{g} / \mathrm{ml})$ were incubated in a $\mathrm{KCl}$ buffer at $37^{\circ} \mathrm{C}$ in the presence of $1 \mu \mathrm{g} / \mathrm{ml}$ oligomycin and $200 \mu \mathrm{M}$ ADP with $5 \mathrm{mM}$ malate and glutamate as respiratory substrates. Indicated doses of minocycline ( $\mathrm{nmol} / \mathrm{mg}$ ) were added prior to start of infusion. CsA $(1 \mu \mathrm{M})$ was used as a positive control, vehicle $\left(\mathrm{H}_{2} \mathrm{O}\right)$ as control and Ruthenium Red (1 $\mu \mathrm{M})$ as negative control. Mitochondria were exposed to a continuous $\mathrm{CaCl}_{2}$ infusion $(200 \mathrm{nmol} / \mathrm{min} / \mathrm{mg}$ ). (B) Calculations of mitochondrial $\mathrm{Ca}^{2+}$-retention capacity in relation to the dose (inserted axis) or the corresponding concentration of minocycline. Values are means \pm SEM. $*$ indicate $p<0.05$, treatment vs. vehicle (control).
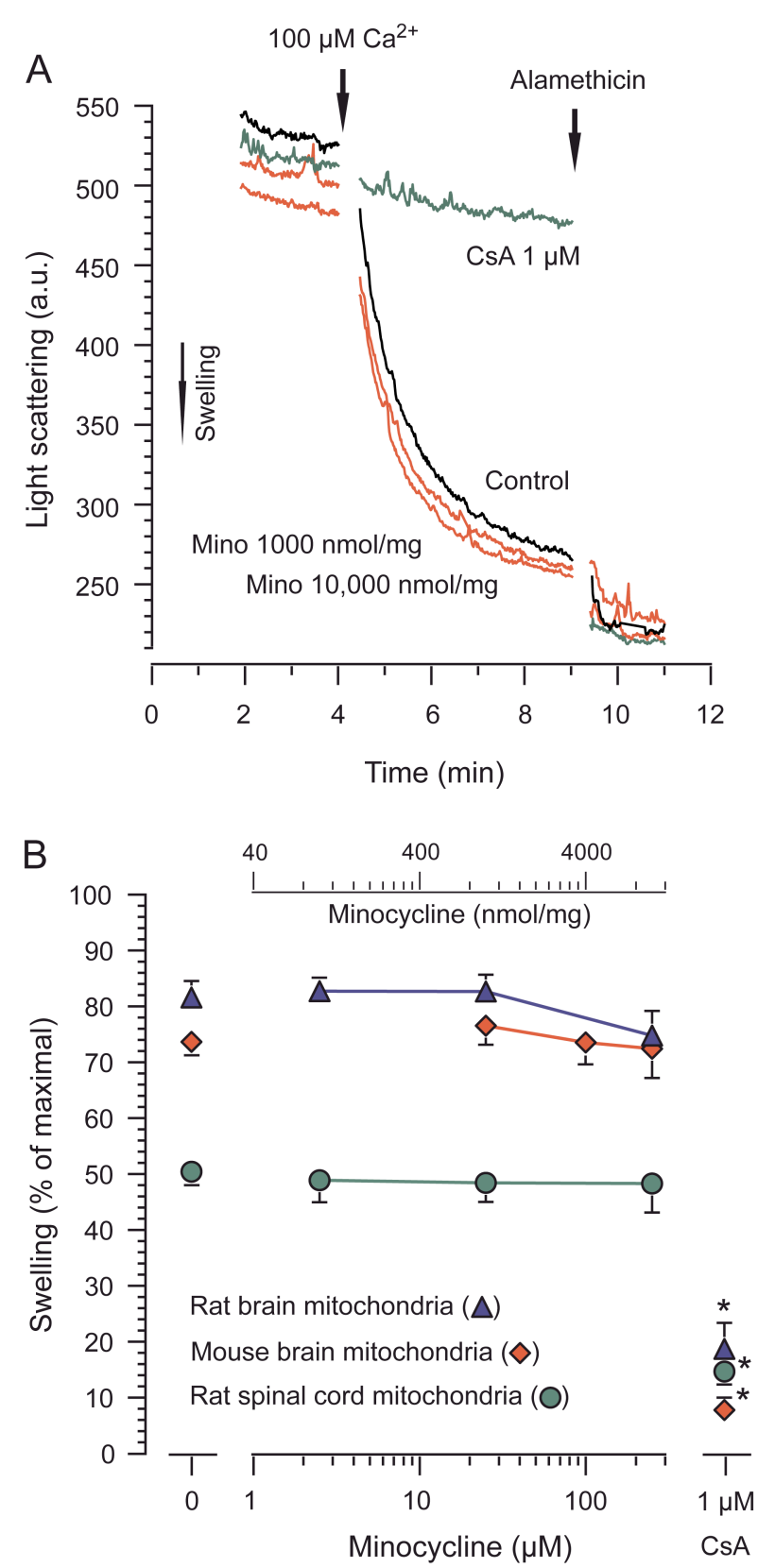

\section{Figure 3}

Minocycline does not inhibit $\mathrm{Ca}^{2+}$-induced swelling of deenergized mitochondria. (A) Representative traces of changes in light scattering (arbitrary units, $520 \mathrm{~nm}$ ). Rat brain mitochondria $(25 \mu \mathrm{g} / \mathrm{ml})$ were run under de-energized conditions at $28^{\circ} \mathrm{C}$ in an isotonic $\mathrm{KCl}$ buffer. The respiratory complexes were inhibited with rotenone and antimycin $\mathrm{A}$, and the $\mathrm{Ca}^{2+}$-ionophore $\mathrm{A} 23187$ was added to ensure equilibration of $\mathrm{Ca}^{2+}$ across the inner mitochondrial membrane. Traces of mitochondria treated with 1000 or $10,000 \mathrm{nmol}$ minocycline/mg mitochondrial protein are displayed. Vehicle $\left(\mathrm{H}_{2} \mathrm{O}\right)$ was used as negative control and $1 \mu \mathrm{m}$ CsA as positive control of $\mathrm{mPT}$ inhibition. Samples were exposed to $100 \mu \mathrm{M} \mathrm{Ca}^{2+}$ for $5 \mathrm{~min}$ followed by alamethicin to induce a standardized maximal swelling response. (B) Calculations of swelling (\% of maximal) in the de-energized model for rat and mouse brain and rat spinal cord mitochondria treated with indicated doses of minocycline, vehicle or CsA. Values are means \pm SEM. ${ }^{*}$ indicate $p<0.05$, treatment vs. vehicle (control). 
In de-energized mitochondria, where the $\mathrm{Ca}^{2+}$ induced $\mathrm{mPT}$ is independent of electrophoretic $\mathrm{Ca}^{2+}$ uptake into mitochondria, minocycline up to $250 \mu \mathrm{M}$ $(10,000 \mathrm{nmol} / \mathrm{mg})$ did not inhibit $\mathrm{mPT}$ in the CNSderived mitochondria studied (Fig. 3).

Minocycline exhibited a dose-dependent reduction of respiratory control ratios (RCR) in rat brain mitochondria oxidizing NADH-linked substrates. At $150 \mu \mathrm{M}(400 \mathrm{nmol} / \mathrm{mg})$ minocycline significantly increased resting respiratory rates (state 2 and 4 ) as well as inhibited ADP-stimulated active phosphorylating rates (state 3) (Table). Similar changes were observed in spinal cord mitochondria, where the same concentration/dose minocycline siginificantly reduced RCR from $5.35 \pm 1.1$ to $1.22 \pm 0.14$. One and $10 \mu \mathrm{M}$ CsA did not affect respiratory states or RCR values (data not shown).

Both $\mathrm{Ca}^{2+}$ (Fig. 4A) and tBid (Fig. 4B) induced significant increases in cyt $c$ detection from background values in rat brain mitochondrial suspensions, from 13.7 and 12.1 to 68.3 and 32.5 $\mathrm{ng} / \mathrm{ml}$, respectively. Minocycline did not inhibit cyt $c$ release following $\mathrm{Ca}^{2+}$-induced $\mathrm{mPT}$ at concentrations up to $20 \mu \mathrm{M}(400 \mathrm{nmol} / \mathrm{mg})$, contrary to $1 \mu \mathrm{M}$ CsA (Fig. 4A). Similar results were obtained for mouse brain mitochondria (data not shown). Neither minocycline nor CsA reduced tBid induced cyt $c$ release in rat brain mitochondria (Fig. 4B). In contrast, $20 \mu \mathrm{M}$ minocycline increased the release of cyt $c$. Control measurements of light scattering revealed that this concentration of minocycline induced slow swelling of energized mitochondria during the incubation period (30 min), whereas tBid alone had no effect on light scattering (data not shown).

\section{Discussion}

Minocycline has displayed convincing neuroprotective properties, with varying effectiveness in different species, experimental models and routes of administration. However, recent investigations in animal models of Huntington's disease (HD), Parkinson's disease and hypoxicischemic brain injury in neonates, have shown minocycline to be ineffective, increasing morbidity and mortality, and it is plausible that the variable and sometimes negative effect of minocycline is related to mode of administration and dose used (Diguet et al., 2004; Smith et al., 2003; Tsuji et al., 2004; Yang et al., 2003). High animal dosing, up to $180 \mathrm{mg} / \mathrm{kg}$, has been employed to reach maximal penetration of the drug into the CNS (Yrjanheikki et al., 1998) or in order to inhibit cyt $c$ release post injury (Teng et al., 2004). The latter objective can be related to the hypothesis that minocycline inhibits cyt $c$ release via mPT inhibition (Teng et al., 2004; Wang et al., 2003; Zhu et al., 2002). In vitro, considerably higher concentrations, $200 \mu \mathrm{M}$, have been used to achieve inhibition of cyt $c$ release from isolated brain mitochondria (Zhu et al., 2002) than concentrations, $0.02 \mu \mathrm{M}$, needed to prevent microglial activation and excitotoxicity (Tikka et al., 2001; Yrjanheikki et al., 1999). In humans with HD a recent clinical study found that $200 \mathrm{mg} /$ day is well tolerated, and in a phase II study of ALS patients the mean tolerated dose was $387 \mathrm{mg} /$ day (Gordon et al., 2004; Huntington Study Group, 2004). The dose commonly used in humans is $3 \mathrm{mg} / \mathrm{kg} /$ day which corresponds to estimated peak CSF concentrations below $10 \mu \mathrm{M}$ (Fagan et al., 2004).

In search of the relevant mechanism for the neuroprotection displayed by minocycline in animal models of ALS and HD, Zhu et al. (Zhu et al., 2002) report inhibition of $\mathrm{Ca}^{2+}$-induced mitochondrial swelling and cyt $c$ release by $200 \mu \mathrm{M}$ minocycline in isolated rat brain mitochondria. They further report an inhibition of tBid-induced cyt $c$ release by $10 \mu \mathrm{M}$ CsA and $100 \mu \mathrm{M}$ minocycline in mouse liver mitochondria. Using the same concentrations, Wang et al. (Wang et al., 2003) detected inhibition of tBidinduced SMAC release in mouse brain mitochondria. In the present study, we replicate the finding that high minocycline dosage can reduce $\mathrm{Ca}^{2+}$-induced swelling in respiring isolated rat and mouse brain mitochondria. However, the characteristics of minocycline were not comparable to those of the classically studied mPT inhibitor CsA. Minocycline increased the swelling response to $\mathrm{Ca}^{2+}$ at lower doses and longer incubations, an effect more pronounced in spinal cord mitochondria. A similar finding has been demonstrated in isolated liver mitochondria where concentrations $\geq 10 \mu \mathrm{M}$ minocycline induced swelling (Cornet et al., 2004).

In energized mitochondria, $\mathrm{Ca}^{2+}$-induced $\mathrm{mPT}$ (measured e.g. as swelling) is dependent on the membrane potential-driven $\mathrm{Ca}^{2+}$ transport into the mitochondrial matrix. Any agent interfering with mitochondrial respiration or $\mathrm{Ca}^{2+}$ transport can consequently diminish activation of $\mathrm{mPT}$ regardless of interaction with the $\mathrm{mPT}$ pore complex. In the present experiments, where minocycline inhibited $\mathrm{Ca}^{2+}$-induced swelling, it concomitantly inhibited 

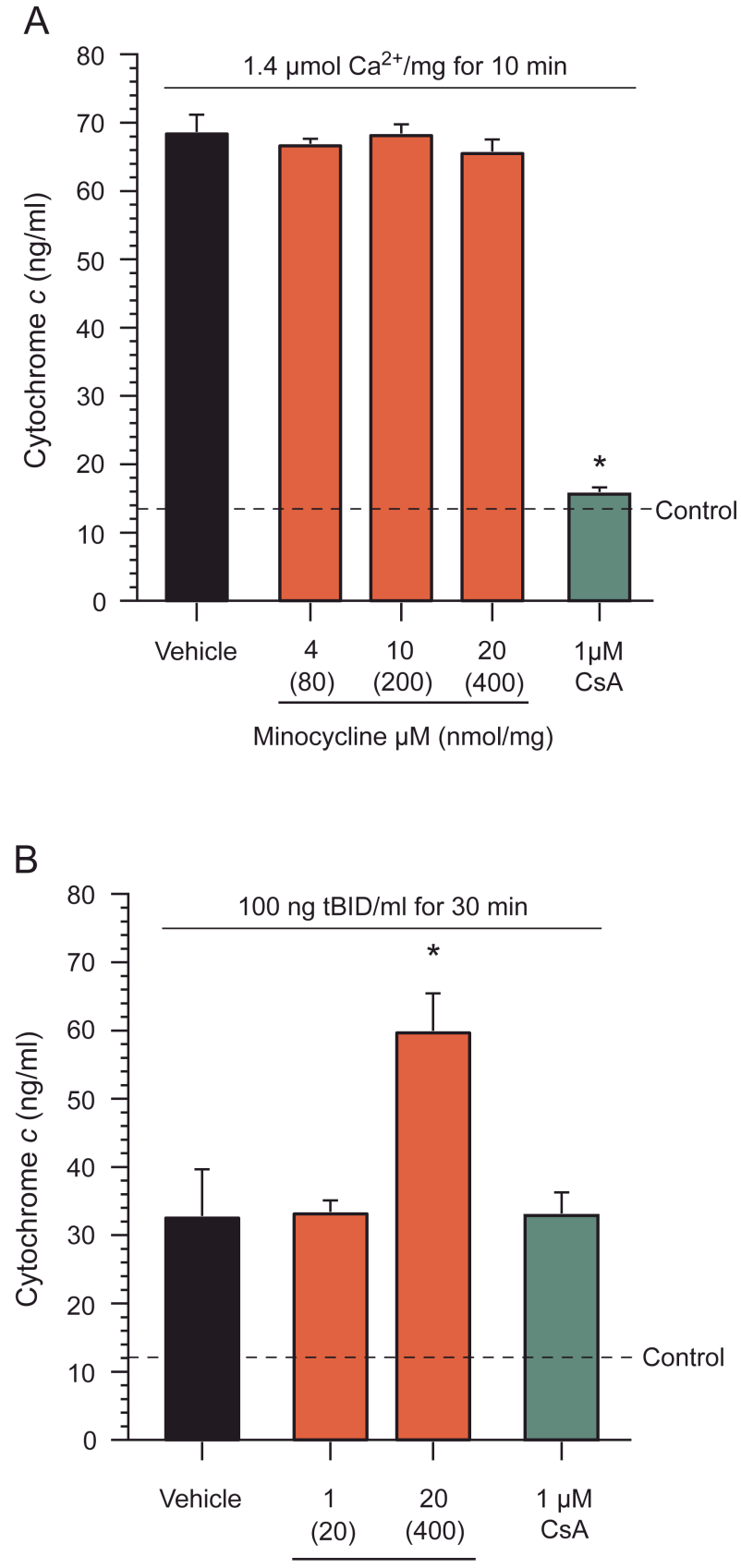

Minocycline $\mu \mathrm{M}(\mathrm{nmol} / \mathrm{mg})$

\section{Figure 4}

Minocycline does not inhibit cyt $c$ release from isolated rat brain mitochondria induced by $\mathrm{Ca}^{2+}$ or tBid. Release of cyt $c$ from mitochondria $(50 \mu \mathrm{g} / \mathrm{ml})$ was evaluated under energized conditions in a sucrose-based buffer at $37^{\circ} \mathrm{C}$ in presence of 1 $\mu \mathrm{g} / \mathrm{ml}$ oligomycin, $20 \mu \mathrm{M}$ ADP and $5 \mathrm{mM}$ malate and glutamate. The indicated concentrations/doses of minocycline were compared to vehicle $\left(\mathrm{H}_{2} \mathrm{O}\right)$ and CsA. Dashed lines indicate cyt $c$ release in control experiments without $\mathrm{Ca}^{2+}$ or tBid additions. (A) Mitochondria were exposed to $1.4 \mu \mathrm{mol} \mathrm{Ca}{ }^{2+} / \mathrm{mg}$ protein $(70$ $\mu \mathrm{M}$ ) for $10 \mathrm{~min}$ or (B) $100 \mathrm{ng} / \mathrm{ml} \mathrm{tBid} \mathrm{for} 30 \mathrm{~min}$. The suspensions were then rapidly chilled, centrifuged twice and the supernatants measured for cyt $c$ content. Values are means + SEM. * indicate $p<0.05$ for CsA or minocycline treatment compared to vehicle. mitochondrial $\mathrm{Ca}^{2+}$ uptake. Thus, minocycline did not appear to act through increased mitochondrial resistance to calcium overload. In contrast, minocycline was found to dose-dependently decrease mitochondrial $\mathrm{Ca}^{2+}$ retention capacity (CRC) with a significant reduction already at $40 \mathrm{nmol} / \mathrm{mg}(2 \mu \mathrm{M})$ i.e. the mitochondria underwent $\mathrm{mPT}$ at a lower $\mathrm{Ca}^{2+}$ threshold.

The CRC as determined in the calcium-infusion experiments would be expected to be very sensitive to depolarization as a decreased proton gradient will acidify the mitochondrial matrix and hence reduce the ability to retain free calcium ions as calcium phosphate complexes (Chalmers et al., 2003). Indeed, previous reports have demonstrated a dose-dependent depolarizing effect of minocycline at concentrations lower than those required for inhibition of $\mathrm{Ca}^{2+}$ induced swelling and show an inhibition of respiratory complex II/III at high concentration (Fernandez-Gomez et al., 2005; Zhu et al., 2002). Here, we demonstrate a dose-dependent reduction in respiratory control by minocyline, with a pronounced uncoupling effect (increased resting respiratory rates) detected at $400 \mathrm{nmol} / \mathrm{mg}(150 \mu \mathrm{M})$. At this dose of minocycline, the CRC was abolished. Depolarization of the membrane potential also sensitizes mitochondria to $\mathrm{mPT}$ induction (Petronilli et al., 1993). However, the uncoupling and depolarization caused by $4000 \mathrm{nmol} / \mathrm{mg}(100 \mu \mathrm{M})$ likely lowers the electrophoretic driving force for $\mathrm{Ca}^{2+}$ below the threshold for its uptake, thereby preventing mPT. The degree of uncoupling can thereby explain the dual effects of minocycline in the mPT assays; partial uncoupling sensitizes the mitochondria to $\mathrm{Ca}^{2+}$ at lower concentrations whereas extensive uncoupling inhibits $\mathrm{mPT}$ by completely inhibiting calcium uptake. Extensive uncoupling by the protonophore CCCP $(0.4 \mu \mathrm{M})$ similarly inhibited swelling and calcium uptake, whereas lower concentrations increased sensitivity towards $\mathrm{Ca}^{2+}$ (data not shown). CsA on the other hand increased mitochondrial CRC as has previously been demonstrated for brain and liver mitochondria (Chalmers et al., 2003) and did not affect respiratory parameters.

The de-energized (non-respiring) model employed in the present study is another well-characterized approach to examine mPT (Bernardi, 1992; Halestrap et al., 1990; Hansson et al., 2003; Hunter et al., 1979). 


\begin{tabular}{|c|c|c|c|c|c|c|}
\hline \multicolumn{2}{|c|}{ Minocycline } & \multirow{2}{*}{$\begin{array}{c}\text { State } 2 \\
\text { (no Minocycline) }\end{array}$} & \multirow{2}{*}{ State 2} & \multirow{2}{*}{ State 3} & \multirow{2}{*}{ State 4} & \multirow{2}{*}{$\mathrm{RCR}$} \\
\hline $\mathrm{nmol} / \mathrm{mg}$ & $\mu M$ & & & & & \\
\hline 0 & 0 & $20.4 \pm 4.0$ & $21.8 \pm 3.8$ & $150.7 \pm 24.1$ & $22.0 \pm 2.8$ & $6.83 \pm 0.24$ \\
\hline 40 & 15 & $22.8 \pm 6.7$ & $25.1 \pm 4.7$ & $148.9 \pm 13.9$ & $22.9 \pm 0.86$ & $6.51 \pm 0.81$ \\
\hline 200 & 75 & $21.6 \pm 2.2$ & $29.4 \pm 0.76$ & $114.9 \pm 13.4$ & $29.3 \pm 1.6$ & $3.92 \pm 0.25^{*}$ \\
\hline 400 & 150 & $22.8 \pm 4.9$ & $38.3 \pm 3.3^{*}$ & $91.5 \pm 13.5^{*}$ & $47.8 \pm 5.8^{*}$ & $1.95 \pm 0.48^{*}$ \\
\hline
\end{tabular}

\section{Table}

Minocycline dose-dependently interferes with mitochondrial respiration. Respiratory rates of brain mitochondrial preparations $(0.25 \mathrm{mg} / \mathrm{ml})$ oxidizing $5 \mathrm{mM}$ malate and $5 \mathrm{mM}$ glutamate. State 2 (no minocycline) denotes oxygen consumption prior to minocycline addition. Rates are means $\pm \mathrm{SD}\left(\mathrm{nmol} \mathrm{O}_{2} / \mathrm{min} / \mathrm{mg}\right) . *=$ statistically significant from respective control value.

Here, respiration is purposely pharmacologically blocked and a $\mathrm{Ca}^{2+}$ ionophore is usually used to ensure free $\mathrm{Ca}^{2+}$ equilibration over the inner membrane so that mitochondrial $\mathrm{Ca}^{2+}$ uptake no longer depends on respiration or membrane potential. The de-energized model thus minimizes the possibility of confounding influence and enables more direct effects of minocycline on $\mathrm{mPT}$ to be studied in a very wide concentration range. No inhibition of $\mathrm{mPT}$ in brain or spinal cord mitochondria was detected by minocycline in this model.

Zhu et al. report an inhibition of $\mathrm{Ca}^{2+}$-induced cyt $c$ release by $200 \mu \mathrm{M}$ minocycline in isolated rat brain mitochondria and tBid-induced cyt $c$ release by 10 $\mu \mathrm{M}$ CsA and $100 \mu \mathrm{M}$ minocycline in mouse liver mitochondria ( $\mathrm{Zhu}$ et al., 2002). Using the latter concentrations Wang et al. (Wang et al., 2003) detected inhibition of tBid-induced SMAC release in mouse brain mitochondria. Similarly to the swelling experiments, the concentrations of minocycline used (also when converted to dose/mg protein) would be expected to affect mitochondrial respiration, membrane potential and consequently $\mathrm{Ca}^{2+}$ uptake. In our hands, minocycline did not inhibit $\mathrm{Ca}^{2+}$-induced, $\mathrm{mPT}$-mediated cyt $c$ release, when evaluated at doses up to $400 \mathrm{nmol} / \mathrm{mg}(20 \mu \mathrm{M})$. Neither did minocycline nor CsA prevent tBid-induced cyt $c$ release from isolated brain mitochondria. Higher doses than 400 $\mathrm{nmol} / \mathrm{mg}$ were not tested due to the effect of minocycline on respiration and $\mathrm{Ca}^{2+}$ uptake, and as the highest dose of minocycline significantly increased cyt $c$ release in the tBid experiments due to slow induction of swelling. In agreement with our findings, Brustovetsky et al. (Brustovetsky et al., 2003) has previously demonstrated that tBid-induced cyt $c$ release is CsA and $\mathrm{mPT}$ independent.

We conclude that minocycline does not demonstrate features of $\mathrm{mPT}$ inhibition in isolated CNS mitochondria even though an apparent inhibition of swelling can be detected at a dose where mitochondrial respiration is affected and $\mathrm{Ca}^{2+}$ uptake inhibited. One may argue that the resulting inhibition of $\mathrm{Ca}^{2+}$ uptake can be beneficial, but at least under the experimental conditions employed in this study, mitochondria were more sensitive towards $\mathrm{mPT}$ induction at intermediate minocycline concentrations. Further, the negative effects of minocycline on the respiratory states of CNS mitochondria are likely not compatible with the high energy demand of neuronal cells, in particular motor neurons of the spinal cord, and could contribute to the toxicity of minocycline in animals and humans at high dosing. Minocycline may prove to have direct beneficial mitochondrial targets at clinically relevant concentrations but the results in this study argue against a direct inhibition of $\mathrm{mPT}$, mPT-mediated or tBid-induced cyt $c$ release.

\section{Acknowledgements}

Financial support is acknowledged from the Swedish Research Council (Project no. 08644), the Swedish Society of Medicine and the Laerdal, Bergvall, and Åhlén foundations. Author E. E. is co-founder of Maas Biolab, 
LLC and NeuroPharma AB, which hold intellectual property rights and develop mitochondrial protective agents for neurological treatment. The authors are grateful to Gary Fiskum for useful methodological input and to Tadeusz Wieloch and Olle Lindvall for support.

\section{References}

Arvin, K.L., Han, B.H., Du, Y., Lin, S.Z., Paul, S.M., Holtzman, D.M., 2002. Minocycline markedly protects the neonatal brain against hypoxic-ischemic injury. Ann Neurol. 52, 54-61.

Bernardi, P., 1992. Modulation of the mitochondrial cyclosporin A-sensitive permeability transition pore by the proton electrochemical gradient. Evidence that the pore can be opened by membrane depolarization. J Biol Chem. 267, 8834-8839.

Bradford, M.M., 1976. A Rapid and Sensitive Method for the Quantitation of Microgram Quantities of Protein Utilizing the Principle of Protein-Dye Binding. Anal Biochem. 72, 248-254.

Brustovetsky, N., Dubinsky, J.M., Antonsson, B., Jemmerson, R., 2003. Two pathways for tBIDinduced cytochrome $\mathrm{c}$ release from rat brain mitochondria: BAK- versus BAX-dependence. J Neurochem. 84, 196-207.

Casarejos, M.J., Menendez, J., Solano, R.M., Rodriguez-Navarro, J.A., Garcia de Yebenes, J., Mena, M.A., 2006. Susceptibility to rotenone is increased in neurons from parkin null mice and is reduced by minocycline. J Neurochem. 97, 934-946.

Chalmers, S., Nicholls, D.G., 2003. The relationship between free and total calcium concentrations in the matrix of liver and brain mitochondria. J Biol Chem. 278, 19062-19070.

Chen, M., Ona, V.O., Li, M., Ferrante, R.J., Fink, K.B., Zhu, S., Bian, J., Guo, L., Farrell, L.A., Hersch, S.M., Hobbs, W., Vonsattel, J.P., Cha, J.H., Friedlander, R.M., 2000. Minocycline inhibits caspase- 1 and caspase-3 expression and delays mortality in a transgenic mouse model of Huntington disease. Nat Med. 6, 797-801.

Choi, S.H., Lee da, Y., Chung, E.S., Hong, Y.B., Kim, S.U., Jin, B.K., 2005. Inhibition of thrombininduced microglial activation and NADPH oxidase by minocycline protects dopaminergic neurons in the substantia nigra in vivo. J Neurochem. 95, 17551765.

Cornet, S., Spinnewyn, B., Delaflotte, S., Charnet, C., Roubert, V., Favre, C., Hider, H., Chabrier, P.E., Auguet, M., 2004. Lack of evidence of direct mitochondrial involvement in the neuroprotective effect of minocycline. Eur J Pharmacol. 505, 111119.

Damiano, M., Starkov, A.A., Petri, S., Kipiani, K., Kiaei, M., Mattiazzi, M., Flint Beal, M., Manfredi, G., 2006. Neural mitochondrial $\mathrm{Ca} 2+$ capacity impairment precedes the onset of motor symptoms in G93A Cu/Zn-superoxide dismutase mutant mice. J Neurochem. 96, 1349-1361.

Diguet, E., Fernagut, P.O., Wei, X., Du, Y., Rouland, R., Gross, C., Bezard, E., Tison, F., 2004. Deleterious effects of minocycline in animal models of Parkinson's disease and Huntington's disease. Eur J Neurosci. 19, 3266-3276.

Du, Y., Ma, Z., Lin, S., Dodel, R.C., Gao, F., Bales, K.R., Triarhou, L.C., Chernet, E., Perry, K.W., Nelson, D.L., Luecke, S., Phebus, L.A., Bymaster, F.P., Paul, S.M., 2001. Minocycline prevents nigrostriatal dopaminergic neurodegeneration in the MPTP model of Parkinson's disease. Proc Natl Acad Sci U S A. 98, 14669-14674.

Fagan, S.C., Edwards, D.J., Borlongan, C.V., Xu, L., Arora, A., Feuerstein, G., Hess, D.C., 2004. Optimal delivery of minocycline to the brain: implication for human studies of acute neuroprotection. Exp Neurol. 186, 248-251.

Fernandez-Gomez, F.J., Galindo, M.F., GomezLazaro, M., Gonzalez-Garcia, C., Cena, V., Aguirre, N., Jordan, J., 2005. Involvement of mitochondrial potential and calcium buffering capacity in minocycline cytoprotective actions. Neuroscience. 133, 959-967.

Festoff, B.W., Ameenuddin, S., Arnold, P.M., Wong, A., Santacruz, K.S., Citron, B.A., 2006. Minocycline neuroprotects, reduces microgliosis, and inhibits caspase protease expression early after spinal cord injury. J Neurochem. 97, 1314-1326.

Friberg, H., Ferrand-Drake, M., Bengtsson, F., Halestrap, A.P., Wieloch, T., 1998. Cyclosporin A, but not FK 506, protects mitochondria and neurons against hypoglycemic damage and implicates the mitochondrial permeability transition in cell death. J. Neurosci. 18, 5151-5159.

Gordon, P.H., Moore, D.H., Gelinas, D.F., Qualls, C., Meister, M.E., Werner, J., Mendoza, M., Mass, J., Kushner, G., Miller, R.G., 2004. Placebo-controlled phase I/II studies of minocycline in amyotrophic lateral sclerosis. Neurology. 62, 1845-1847.

Halestrap, A.P., Clarke, S.J., Javadov, S.A., 2004. Mitochondrial permeability transition pore opening during myocardial reperfusion--a target for cardioprotection. Cardiovasc Res. 61, 372-385. 
Halestrap, A.P., Davidson, A.M., 1990. Inhibition of $\mathrm{Ca} 2(+)$-induced large-amplitude swelling of liver and heart mitochondria by cyclosporin is probably caused by the inhibitor binding to mitochondrial-matrix peptidyl-prolyl cis-trans isomerase and preventing it interacting with the adenine nucleotide translocase. Biochem J. 268, 153-160.

Hansson, M.J., Månsson, R., Mattiasson, G., Ohlsson, J., Karlsson, J., Keep, M.F., Elmér, E., 2004. Brain-derived respiring mitochondria exhibit homogeneous, complete and cyclosporin-sensitive permeability transition. J Neurochem. 89, 715-729.

Hansson, M.J., Persson, T., Friberg, H., Keep, M.F., Rees, A., Wieloch, T., Elmér, E., 2003. Powerful cyclosporin inhibition of calcium-induced permeability transition in brain mitochondria. Brain Res. 960, 99-111.

Hunter, D.R., Haworth, R.A., 1979. The Ca2+induced membrane transition in mitochondria. I. The protective mechanisms. Arch Biochem Biophys. 195, 453-459.

Huntington Study Group, 2004. Minocycline safety and tolerability in Huntington disease. Neurology. 63, 547-549.

Karlsson, J., Fong, K.S., Hansson, M.J., Elmer, E., Csiszar, K., Keep, M.F., 2004. Life span extension and reduced neuronal death after weekly intraventricular cyclosporin injections in the G93A transgenic mouse model of amyotrophic lateral sclerosis. J Neurosurg. 101, 128-137.

Keep, M., Elmér, E., Fong, K.S., Csiszar, K., 2001. Intrathecal cyclosporin prolongs survival of latestage ALS mice. Brain Res. 894, 327-331.

Kraus, R.L., Pasieczny, R., Lariosa-Willingham, K., Turner, M.S., Jiang, A., Trauger, J.W., 2005. Antioxidant properties of minocycline: neuroprotection in an oxidative stress assay and direct radical-scavenging activity. J Neurochem. 94, 819-827.

Kriz, J., Nguyen, M.D., Julien, J.P., 2002. Minocycline slows disease progression in a mouse model of amyotrophic lateral sclerosis. Neurobiol Dis. 10, 268-278.

Matsumoto, S., Friberg, H., Ferrand-Drake, M., Wieloch, T., 1999. Blockade of the mitochondrial permeability transition pore diminishes infarct size in the rat after transient middle cerebral artery occlusion. J. Cereb. Blood Flow Metab. 19, 736-741. Petronilli, V., Cola, C., Massari, S., Colonna, R., Bernardi, P., 1993. Physiological effectors modify voltage sensing by the cyclosporin A-sensitive permeability transition pore of mitochondria. J Biol Chem. 268, 21939-21945.

Ryu, J.K., Franciosi, S., Sattayaprasert, P., Kim, S.U., McLarnon, J.G., 2004. Minocycline inhibits neuronal death and glial activation induced by betaamyloid peptide in rat hippocampus. Glia. 48, 85-90.

Sanchez Mejia, R.O., Ona, V.O., Li, M., Friedlander, R.M., 2001. Minocycline reduces traumatic brain injury-mediated caspase- 1 activation, tissue damage, and neurological dysfunction. Neurosurgery. 48, 1393-1399; discussion 1399-1401.

Scarabelli, T.M., Stephanou, A., Pasini, E., Gitti, G., Townsend, P., Lawrence, K., Chen-Scarabelli, C., Saravolatz, L., Latchman, D., Knight, R., Gardin, J., 2004. Minocycline inhibits caspase activation and reactivation, increases the ratio of XIAP to smac/DIABLO, and reduces the mitochondrial leakage of cytochrome $\mathrm{C}$ and smac/DIABLO. J Am Coll Cardiol. 43, 865-874.

Sims, N., 1990. Rapid isolation of metabolically active mitochondria from rat brain and subregions using percoll density gradient centrifugation. J Neurochem. 55, 698-707.

Smith, D.L., Woodman, B., Mahal, A., Sathasivam, K., Ghazi-Noori, S., Lowden, P.A., Bates, G.P., Hockly, E., 2003. Minocycline and doxycycline are not beneficial in a model of Huntington's disease. Ann Neurol. 54, 186-196.

Sullivan, P.G., Thompson, M., Scheff, S.W., 2000. Continuous infusion of cyclosporin A postinjury significantly ameliorates cortical damage following traumatic brain injury. Exp. Neurol. 161, 631-637.

Teng, Y.D., Choi, H., Onario, R.C., Zhu, S., Desilets, F.C., Lan, S., Woodard, E.J., Snyder, E.Y., Eichler, M.E., Friedlander, R.M., 2004. Minocycline inhibits contusion-triggered mitochondrial cytochrome c release and mitigates functional deficits after spinal cord injury. Proc Natl Acad Sci U S A. 101, 30713076.

Tikka, T., Fiebich, B.L., Goldsteins, G., Keinanen, R., Koistinaho, J., 2001. Minocycline, a tetracycline derivative, is neuroprotective against excitotoxicity by inhibiting activation and proliferation of microglia. J Neurosci. 21, 2580-2588.

Tsuji, M., Wilson, M.A., Lange, M.S., Johnston, M.V., 2004. Minocycline worsens hypoxic-ischemic brain injury in a neonatal mouse model. Exp Neurol. 189, 58-65.

Uchino, H., Elmér, E., Uchino, K., Li, P.A., He, Q.P., Smith, M.L., Siesjö, B.K., 1998. Amelioration by cyclosporin $\mathrm{A}$ of brain damage in transient 
forebrain ischemia in the rat. Brain Res. 812, 216226.

Van Den Bosch, L., Tilkin, P., Lemmens, G., Robberecht, W., 2002. Minocycline delays disease onset and mortality in a transgenic model of ALS. Neuroreport. 13, 1067-1070.

Wang, J., Wei, Q., Wang, C.Y., Hill, W.D., Hess, D.C., Dong, Z., 2004. Minocycline up-regulates Bcl2 and protects against cell death in mitochondria. $\mathrm{J}$ Biol Chem. 279, 19948-19954.

Wang, X., Zhu, S., Drozda, M., Zhang, W., Stavrovskaya, I.G., Cattaneo, E., Ferrante, R.J., Kristal, B.S., Friedlander, R.M., 2003. Minocycline inhibits caspase-independent and -dependent mitochondrial cell death pathways in models of Huntington's disease. Proc Natl Acad Sci U S A. 100, 10483-10487.

Yang, L., Sugama, S., Chirichigno, J.W., Gregorio, J., Lorenzl, S., Shin, D.H., Browne, S.E., Shimizu, Y., Joh, T.H., Beal, M.F., Albers, D.S., 2003. Minocycline enhances MPTP toxicity to dopaminergic neurons. J Neurosci Res. 74, 278-285.
Yong, V.W., Wells, J., Giuliani, F., Casha, S., Power, C., Metz, L.M., 2004. The promise of minocycline in neurology. Lancet Neurol. 3, 744751.

Yrjanheikki, J., Keinanen, R., Pellikka, M., Hokfelt, T., Koistinaho, J., 1998. Tetracyclines inhibit microglial activation and are neuroprotective in global brain ischemia. Proc Natl Acad Sci U S A. 95, 15769-15774.

Yrjanheikki, J., Tikka, T., Keinanen, R., Goldsteins, G., Chan, P.H., Koistinaho, J., 1999. A tetracycline derivative, minocycline, reduces inflammation and protects against focal cerebral ischemia with a wide therapeutic window. Proc Natl Acad Sci U S A. 96, 13496-13500.

Zhu, S., Stavrovskaya, I.G., Drozda, M., Kim, B.Y., Ona, V., Li, M., Sarang, S., Liu, A.S., Hartley, D.M., Wu du, C., Gullans, S., Ferrante, R.J., Przedborski, S., Kristal, B.S., Friedlander, R.M., 2002. Minocycline inhibits cytochrome c release and delays progression of amyotrophic lateral sclerosis in mice. Nature. 417, 74-78. 